Journal of Southeast Asian

\title{
Three Poems: The Room; Man Lost in Long Beach; Oversea Patriots
}

Bunkong Tuon tuonb@union.edu

Follow this and additional works at: https://docs.lib.purdue.edu/jsaaea

Part of the Bilingual, Multilingual, and Multicultural Education Commons

\section{Recommended Citation}

Tuon, Bunkong (2021) "Three Poems: The Room; Man Lost in Long Beach; Oversea Patriots," Journal of Southeast Asian American Education and Advancement. Vol. 16 : Iss. 1, Article 2.

DOI: $10.7771 / 2153-8999.1232$

Available at: https://docs.lib.purdue.edu/jsaaea/vol16/iss1/2

This document has been made available through Purdue e-Pubs, a service of the Purdue University Libraries. Please contact epubs@purdue.edu for additional information.

This is an Open Access journal. This means that it uses a funding model that does not charge readers or their institutions for access. Readers may freely read, download, copy, distribute, print, search, or link to the full texts of articles. This journal is covered under the CC BY-NC-ND license. 


\title{
USAAEA Journal of Southeast Asian American Education and Advancement
}

Vol. 16 Iss. 1 (2021)

\author{
WWW.JSAAEA.org
}

\section{Creative and Literary Works}

\section{Three Poems}

\author{
Bunkong Tuon \\ Union College
}

\section{The Room}

The house is perfect.

A three-story colonial.

Four bedrooms, two baths, kitchen and living room, sunroom that overlooks half an acre of yard. I could see children running in that green. The neighborhood is quiet. School within walking distance and in an excellent district. The fire and police stations are a few blocks away. My wife and I look at each other. Our realtor disappears. "This is the one," I say. She says, "The dining room is too small."

Driving back I think about my first home in America. A red building complex where the bricks crumbled, fell on unsuspected passersby. Fifteen of us crammed in

\footnotetext{
(C)

SDIRERIGHISRESERNEDReaders are free to copy, display, and distribute this article, as long as the work is attributed to the author(s) and the Journal of Southeast Asian American Education \& Advancement, it is distributed for non-commercial purposes only, and no alteration or transformation is made in the work. More details of this Creative Commons license are available at http://creativecommons.org/licenses/by-nc-nd/3.0/. All other uses must be approved by the author(s) or JSAAEA. Journal of Southeast Asian American Education \& Advancement, Vol. 16. Iss. 1. (2021) ISSN: 2153-8999
} 
a two-bedroom apartment.

We were happy to have

non-dirt floor to sleep on,

roof over our heads,

running water to drink, and blue flame rising with the turn of a knob. At night we huddled to keep our bodies warm.

I cocooned in Grandma's arms on the torn yellow couch that became a bed at night. Unmarried aunts wrapped in gray blankets on the floor. One uncle who survived a Khmer Rouge prison slept in the dining room. At night he moved the chairs, swept the floor, pushed the dining table into the hallway, made a bed of two blankets, his arms behind his head, and slept like never before.

\section{Man Lost in Long Beach}

When the demons return his wife's eyes turn eggshell white.

The man with ashen hair and tired eyes throws a bottle, shatters it against the white cupboard. He walks out onto Anaheim, takes a right on Walnut towards the Pacific Ocean he once flew over some twenty five years ago.

He survived the killing fields by pretending to be a farmer, while others were taken, plastic bags muffled 
their screams.

Hiding his name

in a paper boat,

he watched childhood

float away.

His parents shot

point blank.

His mother's eyes

bulging white

and open forever.

\section{Oversea Patriots}

My friend asked,

"Why waste time translating?"

I was a doctoral student

in Comparative Literature.

He persisted, "Who reads

Khmer poetry anyway?"

We were having lunch

in the university courtyard.

"When I graduate, I'm going

back to Kampuchea

and build me a business

in making computers.

You'll see how I rebuild

our Angkor Empire." 

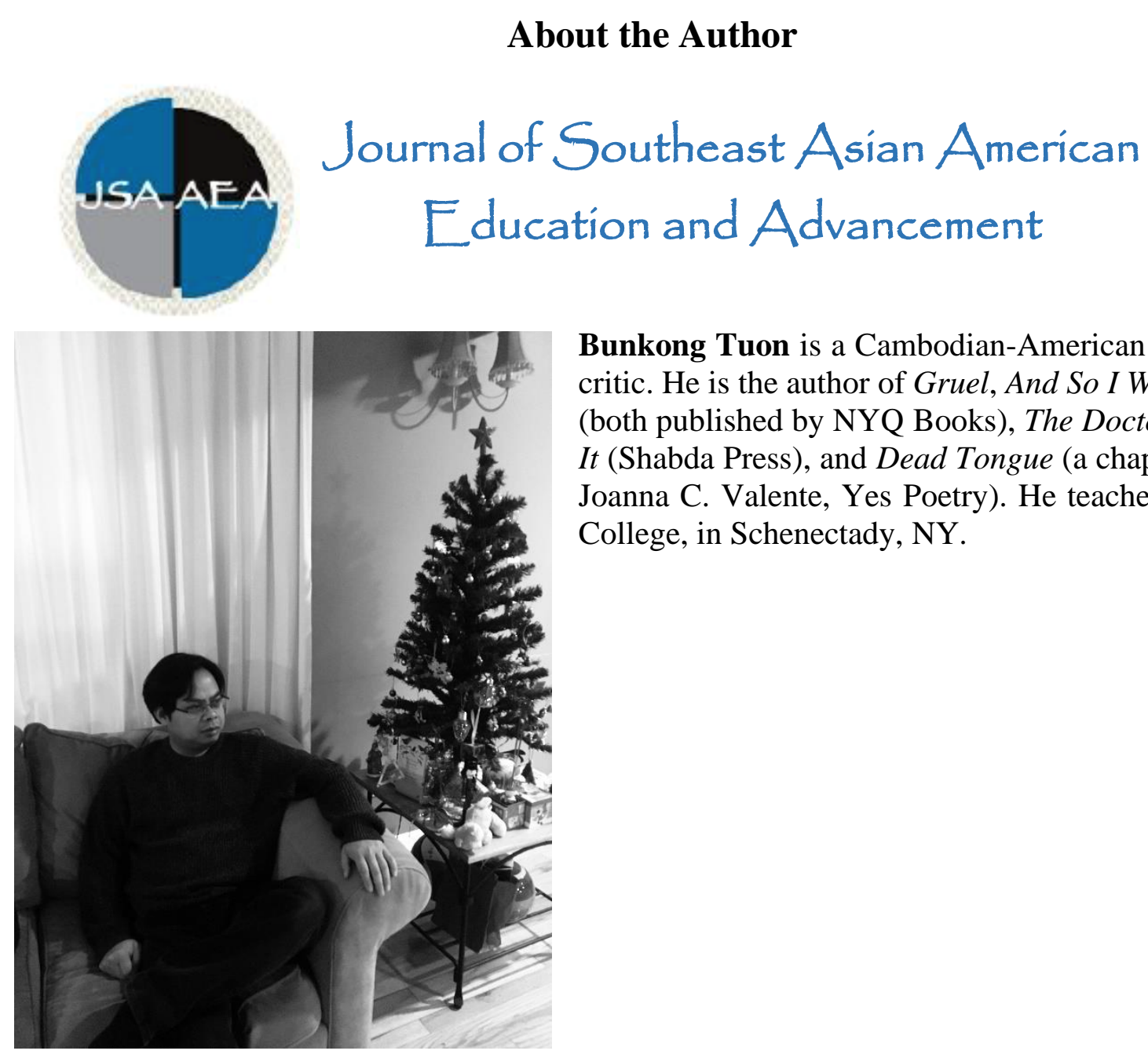

Bunkong Tuon is a Cambodian-American writer and critic. He is the author of Gruel, And So I Was Blessed (both published by NYQ Books), The Doctor Will Fix It (Shabda Press), and Dead Tongue (a chapbook with Joanna C. Valente, Yes Poetry). He teaches at Union College, in Schenectady, NY. 


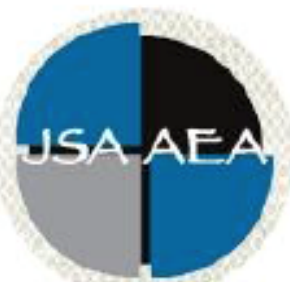

Vol.16 Iss.1 (2021)

\title{
Journal of Southeast Asian American Education and Advancement
}

\author{
Www.JSAAEA.org
}

\section{Editor}

Dr. Wayne E. Wright

Purdue University

Associate Editors

Dr. Chhany Sak-Humphry

University of Hawaii at Manoa

Dr. Phitsamay Sychitkokhong Uy

University of Massachusetts, Lowell

\author{
Book Review Editor \\ Dr. Vichet Chhuon \\ University of Minnesota \\ Creative Works Editor \\ Bryan Thao Worra \\ Lao Assistance Center \\ Journal Manager \\ Chen Li \\ Jeffrey Sovan Wright \\ Purdue University
}

Editorial Review Board

\author{
Dr. Steve Arounsack \\ California State University, Stanislaus \\ Dr. Sovicheth Boun \\ Salem State University \\ Dr. Virak Chan \\ Purdue University \\ Dr. Loan Dao \\ University of Massachusetts Boston
}

\author{
Dr. Carl L. Bankston III \\ Tulane University \\ Dr. Phala Chea \\ Lowell Public Schools \\ Dr. George Chigas \\ University of Massachusetts, Lowell \\ Dr. Hien Duc Do \\ San Jose State University
}




\author{
Dr. Linh Dang \\ KIPP DC Headquarters \\ Dr. Sophal Ear \\ Occidental College \\ Dr. Vincent K. Her \\ University of Wisconsin, Eau Claire \\ Dr. Nancy H. Hornberger \\ University of Pennsylvania \\ Dr. Peter Tan Keo \\ New York University \\ Dr. Yvonne Kwan \\ San Jose State University \\ Dr. Ravy Lao \\ California State University, Los Angeles \\ Dr. Stacey Lee \\ University of Wisconsin, Madison \\ Dr. Jacqueline Mac \\ Northern Illinois University \\ Dr. Bic Ngo \\ University of Minnesota \\ Dr. Leakhena Nou \\ California State University, Long Beach \\ Dr. Mark Pfeifer \\ SUNY Institute of Technology \\ Dr. Loan T. Phan \\ University of New Hampshire \\ Dr. Karen Quintiliani \\ California State University, Long Beach \\ Dr. Angela Reyes \\ Hunter College \\ The City University of New York \\ Dr. Fay Shin \\ California State University, Long Beach \\ Dr. Christine Su \\ College of San Mateo \\ Dr. Alisia Tran \\ Arizona State University \\ Dr. Khatharya Um \\ University of California, Berkeley \\ Dr. Kim Tran \\ University of California, Los Angeles, \\ Glendale Community College \\ Dr. Molly Wiebe \\ The University of Texas at Austin \\ Dr. Changming Duan \\ University of Missouri-Kansas City \\ Dr. Sothy Eng \\ Lehigh University \\ Dr. Jeremy Hein \\ University of Wisconsin, Eau Claire \\ Dr. Peter Nien-Chu Kiang \\ University of Massachusetts, Boston \\ Dr. Kevin K. Kumashiro \\ University of Illinois, Chicago \\ Dr. Ha Lam \\ Independent Scholar \\ Dr. Jonathan H. X. Lee \\ San Francisco State University \\ Dr. Monirith Ly \\ Royal University of Phnom Penh \\ Dr. Sue Needham \\ California State University, Dominguez Hills \\ Dr. Max Niedzwiecki \\ Daylight Consulting Group \\ Dr. Clara Park \\ California State University, Northridge \\ Dr. Giang Pham \\ University of Massachusetts Amherst \\ Dr. Malaphone Phommasa \\ University of California Santa Barbara \\ Dr. Kalyani Rai \\ University of Wisconsin-Milwaukee \\ Dr. Cathy J. Schlund-Vials \\ University of Connecticut, Storrs \\ Dr. Nancy J. Smith-Hefner \\ Boston University \\ Dr. Yer J. Thao \\ Portland State University \\ Dr. Monica M. Trieu \\ Purdue University \\ Dr. Silvy Un \\ Saint Paul Public Schools \\ Dr. Linda Trinh Vo \\ University of California, Irvine \\ Dr. Varaxy Yi Borromeo \\ California State University, Fresno \\ Dr. Yang Sao Xiong \\ The University of Wisconsin-Madison

\section{Dr. Zha Blong Xiong} \\ University of Minnesota
}




\section{Doctoral Student Editorial Review Board}

Diana Chandara
University of Minnesota-Twin Cities
Bao Diep
University of Minnesota-Twin Cities
Vanessa Sovanika Na
University of California San Diego
Khoi Nguyen
George Mason University
Hoa Nha Nguyen
Boston College
Linda Marie Pheng
University of Wisconsin-Madison
Latana Thaviseth
University of California Los Angeles
Melissa Vang
San Diego State University

\author{
Kassandra Chhay \\ University of Minnesota-Twin Cities \\ Annie BichLoan Duong \\ San Joaquin County Office of Education \\ Nielson Hul \\ Cornell University \\ Dung Minh Mao \\ University of Minnesota-Twin Cities \\ Thien-Huong Ninh \\ University of Southern California \\ Krissyvan Truong \\ Claremont Graduate University \\ Mai Vang \\ University of Massachusetts Boston \\ Thong Vang \\ University of Minnesota-Twin Cities
}

Soua Xiong

San Diego State University

Claremont Graduate University 